\title{
A Simple Method for Staining and Counting Isolated Adipose Tissue Fat Cells
}

\author{
E. LoRCH and G. RenTSCH. \\ Department of Experimental Medicine, F. Hoffmann-La Roche \& Co. Ltd., Basle, Switzerland \\ Recoived: May 5, 1969
}

Summary. In similar tests with isolated fat cells from various sources, the total content of triglyceride, in the same way as the amount of DNA which is contained, does not lend itself for use as a basis for comparison. If the number of cells used in the experiment is adopted as a basis for comparison, it is very difficult to distinguish between metabolically active and metabolically inactive cells, just as it is difficult to distinguish between cells and fat droplets. - When stained with acridine orange and a simple cell counting technique used, the fat cells can be counted quickly, and if desired, the count can be repeated with a reasonable degree of accuracy.

Une méthode simple pour colorer et compter les cellules adipeuses isolees.

Résumé. Dans des tests semblables effectués avec des cellules adipeuses isolées venant de sources diverses, la quantité totale de triglycérides ainsi que la quantité de DNA qui se trouve contenue ne se prête pas pour l'utilisation comme base de comparaison. Si le nombre de cellules utilisées dans l'expérience est adopté comme base de com. paraison, il est très difficile de faire la distinction entre les cellules métaboliquement actives et les cellules métaboliquement inactives, de même il est difficile de faire la distinction entre les cellules et les gouttelettes de graisse. Après coloration avec de l'orange acridine et à l'aide d'une technique simple de comptage des cellules, les cellules adipeuses peuvent être comptées rapidement, et si on le désire, le compte peut être répété avec un bon degré de précision.

Eine einfache Methode zur Färbung und Zählung von isolierten Fettzellen

Zusammenfassung. Bei vergleichenden Untersuchungen an isolierten Fettzellen verschiedener Herlxunft ist sowohl der Triglycerid-als auch der DNA-Gehalt der Fettzellen als Bezugsgröße ungeeignet. Verwendet man die Zahl der in dem Versuch eingesetzten Zellen als Bezugsgröße, so ist eine Unterscheidung zwischen metabolisch aktiven und inaktiven Zellen sowie zwischen Zellen und Fett-Tröpfchen sehr schwierig. - Nach Färbung mit Acridinorange und Anwendung einer einfachen Zähl. technik können Fettzellen rasch und gut reproduzierbar ausgezählt werden.

Key-words: Adipose tissue, isolated fat cells, staining of fat cells, cell counting.
Data obtained in experiments with isolated adipose tissue cells are still often presented on the basis of the triglyceride or DNA-content. This may be sufficient when effects in vitro on a single homogeneous cell popu- content as a basis for comparison obviously becomes questionable. The DNA-content should be more appropriate, but in our experience, it is often difficult to wash fat-cells completely free of connective tissue

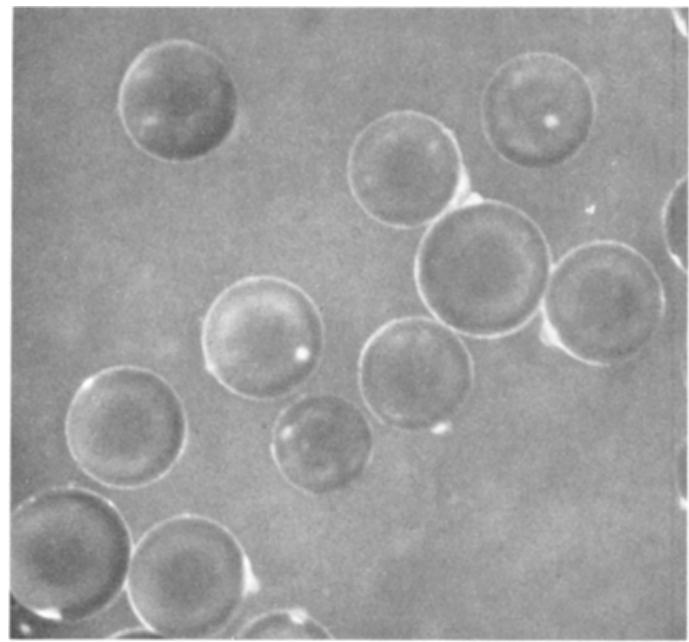

A

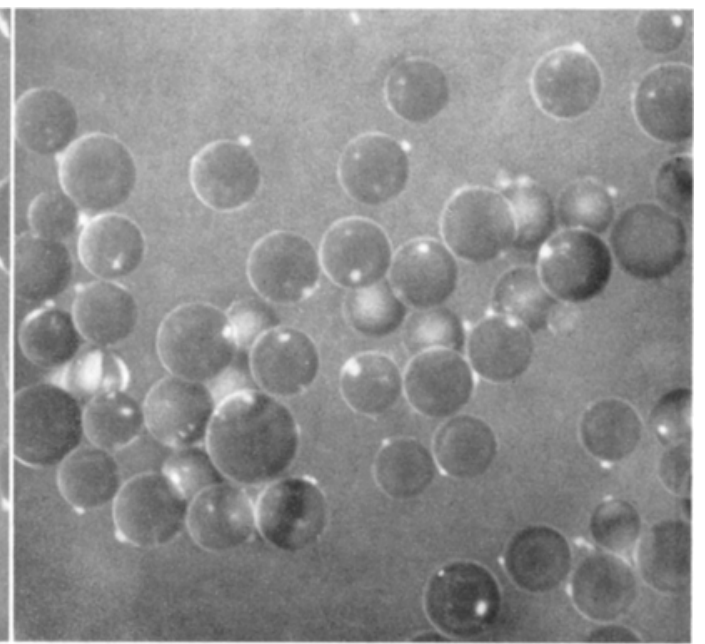

B

Fig. 1. Fat cells from Bar-Harbour obese mice (A) and their lean littermates (B). The cell suspensions were treated with $\mathrm{AO}$ as described in the text. Fluorescence light; total magnification 150 fold.

lation are compared. If, however, metabolic studies are performed on cell suspensions originating from animals of different ages, nutritional states etc., the triglyceride without excessive lysis, as for instance in the case of cells obtained from genetically obese mice.

In comparative studies with different cell popula- 
tions, number of cells seems to be the most reasonable reference basis at present.

We tried, therefore, to find a simple counting technique that would allow results to be reproduced at any time. In counting fat cells, difficulties are encountered since one has to distinguish between living cells, fat droplets and dead cells. Using the fluorescent dye Acridine Orange ( $\mathrm{AO}$ ), the differentiation becomes very easy, because fluorescence of different wavelengths appears after staining a cell population with (AO) [1]. The nuclei of normal, living cells show a green fluorescence, whereas the nuclei of dying or dead cells develop a fluorescence ranging from orange to red. Fat droplets show a pale green fluorescence.

\section{Method}

A rectangular frame $(1 \times 1 \mathrm{~cm})$ was cut out of adhesive tape (of about $0.2 \mathrm{~mm}$ thickness), and was glued to a siliconized microscope slide forming a "trough" for the reception of the cell suspension. With the tape frame facing downwards, a cell suspension $(5 \mu l)$ prepared according to RoDBELL [2] and containing approximately $10^{5}$ cells per $\mathrm{ml}$, was applied from undermeath into the middle of the trough. This application was made with a plastic-tipped pipette (Oxford-sampler or Eppendorf-micropipette) held vertically with the tip pointing upwards, in order to prevent cell loss due to flotation within the pipette tip. The slide was then turned over, and $5 \mu \mathrm{l}$ of a solution of $1 \mathrm{mg}$ of $\mathrm{AO}-\mathrm{HCl}$ in $10 \mathrm{ml}$ of Hanks-solution was added to the cell suspension. The AO sample used was purified chromatographically [3] from commercial material (Fluka AG, Chemische Fabrik, St. Gallen, Switzerland). A siliconized cover slide with a scratched-in millimeter net was put on top of the trough, the millimeter net facing the drop and thus permitting both the cells and the scratched scale to be in focus simultaneously.

After 3-10 min standing at room temperature, the stained cell-suspension was observed in a Zeiss fluorescence microscope at 50-fold magnification. Technical data of microscopy were: UV lamp: Osram HBO 200, high pressure mercury lamp; blue filter BG 23; barrier filter: Zeiss 53, transmitting light of wave length greater than $530 \mathrm{~nm}$. Since the cells floating to the surface of the drop did not seem to be distributed statistically, all the cells of the drop were counted. Using the same original cell suspension, 6 consecutive countings performed in this manner gave, for example, the following counts: $298,295,306,289,301,292$ cells.

Acknowledgement. The authors would like to express their appreciation to Miss ANDY LIPPOK for her skilful technical assistance.

\section{References}

1. Haitrnger, M.: ,Fluoreszenz-Mikroskopie“" 2. Auflage. Leipzig: Akad, Verlagsgesellschaft Geest und Portig $\mathrm{KG}, 1959$.

2. Ropbexc, M.: Metabolism of Isolated Fat Cells. I. Effects of Hormones on Glucose Metabolism and Lipo. lysis. J. biol. Chem. 239, 375-380 (1964).

3. ZANker, V.: Über den Nachweis definierter, reversibler Assoziate (,reversible Polymerisate ") des Acridinorange durch Absorptions- und Fluoreszenzmessungen in wäßriger Lösung. $Z$. physik. Chem. 199, 225-258 (1952).

Dr. E. LORCH

Dr. G. Rentsch

Abtlg. für experimentelle Medizin

F. Hoffmann-La Roche \& Co. CH-4000 Basel 